\title{
PRINSIP-PINSIP ISLAM DALAM AKTIFITAS KOMUNIKASI PEMASARAN DI AGEN PERJALANAN
}

\author{
Eko Putra Boediman, Armaini Lubis \\ Fakultas Ilmu Komunikasi Universitas Budi Luhur Jakarta \\ ekosyahid@yahoo.com \\ armaini.lubis@budiluhur.ac.id
}

\begin{abstract}
The Hajj and Umrah become an annual tradition in Indonesia which must be accompanied by further emergence of travel agents that deliver services of organizing Hajj and Umrah. Hidayah Hasyid Oetama (H2O)Hajj and Umroh travel is practicing several marketing communication mix that is advertising, public relations and publicity, WOM and personal selling. This study discusses the paradigm of marketing communication in the context of Islam. Grand theory of this study is the marketing communication mix (Product, Price, Place, Promotion, and People) and focus on Promotion.This study used a qualitative approach worked with qualitative descriptive method. The paradigm of this research is constructivist and the collected data through interviews and direct observation to be analyzed systematically and thoroughly about Islamic values contained in the promotional activities of PT. H2O. The study stated and concluded that PT. H2O practicing sales and promotion based on the law of Islamic tenet and Syariah. The conclusion is that in Islamic principles, promotion techniques are not justified in using sexual attraction, emotional appeal, the appeal of fear, false testimony and the apparent attractiveness of research, as well as contributing to the ignorance of mind and encourage improvidence.
\end{abstract}

Keywords: Islamicprinciples, Marketingcommunication mix, Promotion

\section{PENDAHULUAN}

PT. Hidayah Hasyid Oetama(PT. $\mathrm{H} 2 \mathrm{O}$ )sebagai perusahaan agen perjalanan ibadah haji dan umroh sejak tahun 1996, kemudian dilembagakan dengan nama PT. H2O pada tahun 2010.Program unggulannya adalah Jalinan Silaturrahim Syariah, Program ini sekaligus membuktikan bahwa perusahaan PT.H2O menjalankan aktifitas promosinya secara islami, disamping itu brosur, pamphlet dan beberapa alat media promosi lainnya tidak mengeksplorasi "aurat", bahasanya pun santun dan tidak provokatif. Paparan tersebut dapat diyakini bahwa PT. H2O ini memang menjalankan aktifitas promosinya secara Islami, hal inilah yang akan dijawab di dalam penelitian ini.

Ciri khas dan keunikan travel $\mathrm{H} 20$ ini adalah dalam hal membuat daya tarik pelanggan dengan programprogram promosinya. Objek penelitian $\mathrm{H} 2 \mathrm{O}$ ini dikategorikan sebagai brand 
syariah karena pelanggannya berbasis ummat muslimin Indonesia.Dari pencermatan fenomena di atas, daya tarik penelitian ini adalah bagaimana prinsip-prinsip / paradigma Islam menyoroti permasalahan tersebut.

Ada beberapa alasan mengapa marketing komunikasi ber-prinsip Islam ini menjadi menarik dan patut dikaji. Pertama, memberikan keuntungan (profit) yang banyak. Sebagaimana fungsinya, marketing komunikasi merupakan salah satu tools yang diharapkan secara efektif dan efisien dapat menghasilkan keuntungan maksimal. Kedua, mendapatkan Berkah (Barokah) Allah SWT. Tatkala semua komunikasi pemasaran dirancang dan dieksekusi tanpa sedikit pun memasukkan cara-cara yang melanggar tata cara Islam seperti berbohong, mengeksploitasi aurat, menggambar (manual) makhluk bernyawa, dan sebagainya, maka "stempel halal" dan keberkahan akan diperoleh. Karenanya itu dibutuhkan rancangan komunikasi pemasaran yang jauh lebih penting dari sekedar kreatif. Ketiga, menciptakan peradaban manusia yang lebih arif, bijaksana dan bermartabat. Marketing komunikasi merupakan bagian dari komunikasi, dan komunikasi adalah proses interaksi (attention, interest, desire, action) antara pemberi dan penerima pesan danada yang diharapkan dalam proses tersebut.

Dengan penjelasan ketiga aspek tersebut, maka marketing komunikasi berprinsip dan berparadigma Islam sebenarnya bukan hanya men-support pertumbuhan bisnis syariah/ non syariah, namun juga sekaligus dapat meraih berkahdan pahala ibadah karena tidak melanggar larangan Allah SWT.Berpijak dari uraian pokok permasalahan, paparan fenomena dan urgensi tersebut diatas, peneliti berhasrat untuk menyoroti dan mengkaji lebih dalam tentang "Prinsipprinsip Islami dalam aktifitas komunikasi pemasaran khususnya promosi" melalui studi kasus penyelenggara haji dan umroh dari travel agent di PT. H2O.

\section{TINJAUAN PUSTAKA}

\section{Teori Komunikasi Pemasaran (Konvensional)}

Sejarah menunjukkan, bahwa Butler dari University of Chicagoadalah orang yang pertama mengadopsi konseppemasaran dari riset-riset penjualan pada tahun 1906. Beliau mengambil istilah-istilah tersebut dari kajian ilmu ekonomi dari pemikiran teoritik Ricardo dan Adam Smith. Pada perkembangannya semenjak tahun 1949, pemasaran (marketing) dianggap lebih luas, tidak hanya menyangkut unsur-unsur penjualan saja, maka kemudian mulailah masuk berbagai unsur didalamnya. KemudianBorden pada tahun 1964 memperkenalkan konsep barunya tentang marketing mix. selanjutnya, kajian komunikasi pemasaran dipastikan dikenal banyak orang setelah terdapat pengembangan dan temuan baru, belakangan diketahui 
bahwa komunikasi pemasaran itu bersifat multidisipliner (Prisgunanto, 2006:28).

Konsep inti pemasaran adalah pertukaran, proses sosial dan managerial dimana individu dan kelompok mendapatkan kebutuhan dan keinginannya dengan menciptakan, menawarkan dan bertukar sesuatu yang bernilai satu sama lain”. Definisi ini didasarkan pada konsep inti: kebutuhan, keinginan, dan permintaan. Kemudian produk yakni nilai, biaya, dan kepuasan. Selanjutnya pertukaran, transaksi, dan hubungan. Terakhir adalah pasar: pemasaran dan pemasar. (Kotler dan AB. Santoso, 2000: 7).

Kegiatan komunikasi pemasaran merupakan rangkaian kegiatan untuk mewujudkan suatu produk, jasa, ide, dengan menggunakan bauran pemasaran (promotion mix): iklan (advertising), penjualan tatap muka (personal selling), promosi penjualan (sales promotion), hubungan masyarakat dan publisitas (public relation and publicity) serta pemasaran langsung (direct marketing) (Purba, dkk, 2006: 126-127).

\section{Komunikasi Pemasaran (Prinsip Islam)}

Dewasa ini sering dijumpai cara pemasaran yang tidak etis, curang dan tidak profesional, halini dapat mengganggu orang lain. Oleh karenanya komunikasi pemasaran kategori konvensional perlu dikaji ulang dan dilihat dari sudut pandang nilai dan aspek Islam. Karena itu peneliti berusaha untuk melakukan re-definisi kata demi kata mengenai "komunikasi" dan "pemasaran" berbasis "prinsip/syariah/aspek/nilai" Islam yang merujuk pada beberapa pendapat/kutipan dan referensi para ahli.

Kertajaya (2005) berpendapat bahwa "kegiatan marketing atau pemasaran seharusnya dikembalikan pada karakteristik yang sebenarnya, yakni relegius, beretika, realistis dan menjunjung tinggi nilai-nilai kemanusiaan. Inilah yang dinamakan marketing syariah, dan inilah konsep terbaik marketing untuk hari ini dan masa depan".

Pemasaran (marketing) prinsip Islam adalah sebuah disiplin bisnis yang seluruh proses, baik proses penciptaan, proses penawaran, maupun proses perubahan nilai (value), tidak boleh ada hal-hal yang bertentangan dengan akad dan prinsip-prinsip muamalah yang Islami (Kertajaya dan Sula, 2006:27).

Pemasaran syariah sendiri menurut definisi adalah "suatu disiplin bisnis strategis yang sesuai dengan nilai dan prinsip syari'ah" (Al Arif, 2010:20).Pemasaran syariah dijalankan didasarioleh prinsip dan konsep keislaman. Jadi nilai inti pemasaran syariah adalah integritas, dan transparansi sehingga marketer tidak boleh bohong dan orang membeli karena butuh dan sesuai dengan keinginan dan kebutuhan, bukan karena daya tarik harga (mis: diskon), daya 
tarik emosional (mis: testimoni tokoh/selebritas/seksualitas) atau imingiming janji hadiah dan penelitian semu belaka.

MenurutKotler, Kertajaya, Huan dan Liu (2003), ada beberapa dimensi yang dapat dijadikan pertimbangan sebagai pembeda antara pemasaran konvesional dan pemasaran prinsip Islam, diantaranya adalah:

a. Prinsip Dasar. Pertama, Prinsip Iman dan Keyakinan atau 'transendental'. Ilmu komunikasi dan pemasaran bila dikaitkan dengan aspek Islami tentu mutlak harus berprinsip dan kaidah Islam. Kedua, Prinsip Operasional. Hukum Islam (Syariah) adalah kerangka kerja frame of work yang meliputi perkataan dan amal (perbuatan) sertainteraksinya dengan seluruh elemen pendukungnya (alat, media).

b. Sistem dan Operasional Perusahaan (Komunikasi Pemasaran Syariah). Aktifitas ini harus berprinsip dasar Islam. Contohnya pada internal perusahaan, hubungan dengan para karyawan, kultur dan tata kelola, etika pergaulan antara laki-laki dan perempuan, sampai etika berpakaian dan tingkah laku. Kesemuanya tersebut haruslah syar'i (menurut aturan dan hukum Islam).

c. Segmentasi. Selama tidak bertentangan dengan "Prinsip Dasar", tidak ada batasan segmentasi. Siapapun tanpa dibatasi oleh apapun bisa menjadi segmen pasar. d. Keuntungan (Profit). Tidak menghalalkan segala cara, sehingga keuntungan yang diperoleh (dalam paradigma Islam) menjadi berkah. Sebuah konsep yang tidak dimiliki oleh sistem konvensional non syariah (contohnya: kapitalis, sosialis).

e. Cakupan kerja. Aktivitas komunikasi pemasaran dapat dilakukan selama: (1) Tidak bertentangan dengan keimanan dan aqidah; (2) Tidak merencanakan, mengkomunikasikan, dan merancang produk yang diharamkan, namun dibuat/dibungkus dengan balutan pencitraan atau hasil penelitian sehingga seolah-olah dapat dihalalkan; (3) Tidak menggunakan ikon atau visualisasi yang dilarang syariah; (4) Tidak menggunakan foto atau gambar makhluk hidup bernyawa, kecuali kartun atau gambar 1 dimensi yang tidak dapat diraba dan tidak sempurna yang tidak mungkin makhluk itu dapat hidup; (5) Tidak ada kebohongan dan kepalsuan.

f. Pola kemitraan/ kerjasama yang syar'i.Hubungan ini adalah amanah yang wajib dipenuhi sesuai kesepakatan kedua pihak. Penyimpangan terhadap amanah dapat merugikan kedua pihak dan berdosa. Teknisnya, kerjasama dilakukan dengan cara: (1) Kerjasama didasarkan pada profesionalitas dan kapabilitas, 
tanpa praktek suap; (2) Mendasarkan pada aqad (perjanjian kerjasama) yang jelas dan tertulis; (3) Kedua pihak saling ridlo (antarodlin), sepakat tanpa ada paksaan dari pihak manapun.

\section{Bauran Pemasaran}

Bauran atau strategi pemasaran merupakan kombinasi dari berbagai tahapan atau elemen yang diperlukan mulai dari tahap perencanaan sampai dengan eksekusi atau pelaksanaan keseluruhan operasi pemasaran (Jefkins, 1997:8).E. Jerome Mc.Carthy adalah orang pertama yang memperkenalkan konsep dasar 4P,lalu dikembangkan oleh Philip Kotler. 4P ini terbagi menjadi empat bagian utama: product (produk),place (tempat),price (harga),promotion (promosi). Bauran pemasaran juga dikatakan sebagai pengelompokkan kiat-kiat pemasaran yang digunakan perusahaan untuk mencapai tujuan pemasarannya dalam pasar sasaran. (Kotler \& Armstrong 2001:5)

\section{Bauran Promosi (Promotional Mix)}

Untuk menghasilkan kebijakan promosi, sebuah perusahaan yang baik harus memperhatikan bauran promosi yang paling efektif. William J. Stanton (2000:60) dalam buku Prinsip Pemasaran, mendefinisikan promotional mix sebagai kombinasi dari penjualan tatap muka, periklanan, promosi penjualan, publisitas dan hubungan masyarakat yang membantu pencapaian tujuan perusahaan.

Menurut definisi tersebut, bauran promosi adalah bagian dari marketing communication mix, yang terdiri dari: Iklan (advertising), dan Promosi penjualan (sales promotion), beberapa tools utama promosi penjualan yang dapat digunakan, adalah:Diskon, Surat jaminan dan Turun harga. (Kotler \& Armstrong 2001:684). Selanjutnya adalah Point-of-purchase (POP)dan terakhir adalah Penjualan pribadi (personal selling) seperti yang dikutip dalam Kotler \& Armstrong (2001:201).

\section{Promosi Penjualan (Sales Promotion)}

Kegiatan promosi tentu harus didukung oleh cara berkomunikasi yang baik, efektif dan tepat sasaran. Komunikator (who) harus menggunakan bahasa yang mudah dimengerti dan memudahkan komunikannya atau pelanggannya (whom) untuk memahami maksud dan tujuan dari promosi penjualan (what) yang disampaikan.

Perihal tersebut seirama dengan firman Allah SWT di dalam penggalan Q.S. An-Nisa ayat 63"Qoulan Baligha" yang berarti menggunakan kata-kata yang efektif, efisien, tepat sasaran, mudah dimengerti sesuai kelas dan tingkatannya serta komunikatif. "Perkataan yang berbekas pada jiwa mereka" bermakna cukup dalam bila dikaitkan dengan komunikasi yang efektif pada kegiatan promosi. Dalam melakukan promosi, komunikasi hendaknya menggunakan bahasa yang 
mudah dipahami oleh target pasar dan pelanggan sehingga pesan yang ingin disampaikan oleh perusahaan maupun komunikator (sales/marketing) dapat diterima dengan baik oleh masyarakat.

\section{Bauran Pemasaran Konvensional dan Bauran Pemasaran Islami}

Bauran pemasaran konvensional yakni 4P's (Product, Price, Place, Promotion) hanya mengedepankan orientasi bisnis. Kini pendekatan pemasaran Syariah memodifikasi dengan acuan filosofi "YouMarketing”, dengan kata lain menempatkan customer dengan istilah "-you". Lalu merubah elemen 4P's menjadi 4C's.

Menurut Damirachi,G., \&Shafai, J (2011)pemasaran 4C's ini merubah cara pandang pola pemasaran konvensional (sales and marketing berhaluan customer-centric. Sementara pemasaran syariah memandangnya sebagai sebuah interaksi silaturrahim, mengedepankan dan melihat dari perspektif pelanggan lebih mendalam.

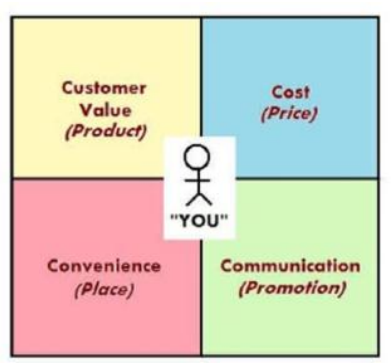

Gambar 1: 4Cs'

\section{Jurnal : A Guideline to Islamic} Marketing Mix

Berikut ini adalah penjabaran dari Gambar 2.1 4Cs:
(1) Customer Value (Not Product!). Bilamana produk adalah sesuatu yang dibuat kemudian manusia datang lalu membeli produk tersebut. Sementara saat ini fokusnya adalah kepada nilai dari seorang customer, apa keinginan pelanggan bukan apa kenginan penjual atau produsen. (2)Cost (Not Price!). Secara terminologi price dan cost sekilas bersinonim, namun menurut perspektif ekonomi price adalah sesuatu yang dibebankan/dibayarkan kepada pelanggan sejumlah yang ditetapkan oleh penjual/pedagang, sementara cost biasanya berasal dari produsen ataupun supplier

(http://www.ncsu.edu/project/).(3)Conv enience (Not Place!). Masyarakat sudah mulai mencari kenyamanan dalam kapan, dimana dan bagaimana caranyaberbelanja. Kenyamanan adalah bagaimana mengoptimalkan seluruh aspek marketing mix sehingga para pelanggan dapat merasakan pengalamannya sendiri yang membuatnya merasa nyaman dan memudahkan pelanggan bertransaksi dan pasca transaksi.(4) Communication (Not Promotion!). Promosi saat ini sudah tidak lagi massive, banyak dan besar. Konsumen sudah tidak hanya menilai dari produk yang "bagus" saja. Konsumen mencari interaksi yang bermakna dan keintiman komunikasi.Komunikasi dua arah untuk membangun hubungan yang baik harus dibina dan dipertahankan. 


\section{Bauran Pemasaran Etika Islam (Islamic Marketing Mix Ethics)}

Agar pemasaran lebih efektif dan powerful maka dibutuhkan pola komunikasi. Dan Islamic Marketing Ethics berpedoman pada prinsip-prinsip persamaan dan keadilan yang membedakannya dengan etika sekuler dalam banyak hal. Ada tiga karakter utama etika (komunikasi) pemasaran dalam perspektif Islam:(1) Etika pasar harus berpedoman pada Al-Qur'an; (2) Penjabaran dari 4Cs diatas mutlak melibatkan aspek keimanan manusia kepada Allah sebagai "hamba Allah".(3) Memaksimalkan nilai dengan sudut pandang yang lebih baik untuk masyarakat dan bukan hanya komoditi bisnis atau mengejar pemaksimalan profit pribadi. (Saeed, Ahmad dan Mukhtar, 2001)

Aktifitas komersil menurut perspektif Islam diatur oleh dua prinsip. Pertama, secara moral tunduk dan patuh kepada perintah Allah. Kedua, kemurahan hati, belas kasih dan empati terhadap seluruh ciptaan Allah yang secara langsung terlihat dari cara menahan diri dari perbuatan menyakiti terhadap sesama dan mencegah penyebaran praktek yang tidak etis. Al'amru bil-ma'ruf wannahyu'anilmun'kar(QS. 31:17), sebuah perintah untuk mengajak kebaikan dan mencegah yang buruk. Berikut adalah gambar integrasi Marketing Mix dengan Communication Mix:

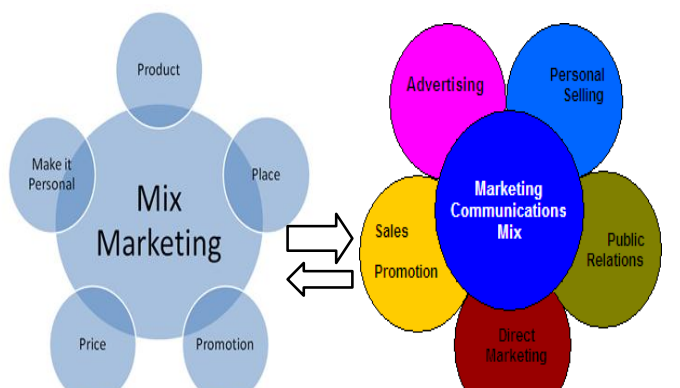

Production Process. Fokus pada proses pembuatan produknya. Perkembangan produk-produk bernafaskan Islam sebaiknya divisualisasikan berbeda dan sebagai pembeda dari produk-produk dengan pemikiran ala "Barat". Ibn alUkhuwwah (1983) menyatakan: (1)Produk sebaiknya sah menurut hukum dan tidak menyebabkan pembodohan pemikiran para konsumen dalam bentuk apapun. (2) Produk harus didukung oleh aset. (3) Produk harus disampaikan/dikirim karena penjualan produk tidak sah jika tidak dapat disampaikan/dikirim.

(4) Ada kebutuhan identifikasi fitur-biaya tambahan ekstra yang secara material dapat mengubah produk atau dampak terhadap keputusan pembelian. (5) Semua pihak berniat untuk melaksanakan kewajiban mereka, keuangan dan sebaliknya, dengan itikad baik; dan harus didasarkan pada prinsip keadilan, kewajaran dan kesetaraan.Melalui pendekatan Islam, tujuan utama dari pengembangan produk yang cocok adalah untuk memberikan, meningkatkan dan memenuhi kebutuhan dasar manusia.Miller (1996) menyatakan 
bahwa etika pengambilan keputusan bagi pebisnis adalah untuk menghasilkan produk-produk dengan strategi sadar biaya (cost consciousstrategy), artinya setiap biaya yang dikeluarkan untuk membuat produk benar-benar dihitung untuk mendapatkan margin profit. Perspektif Islam, di sisi lain, mendorong pendekatan sosial dan kesejahteraan bukan hanya berdasarkan maksimalisasi keuntungan.

\section{Product Promotion Rules.}

Fokus pada promosi produknya. Islam tidak membenarkan dan menutupnutupi perilaku promosi yang menipu dalam formula apapun. Al-Qur'an mengutuk segala bentuk dari pernyataan palsu, tuduhan tidak berdasar, ramuan dan kesaksian palsu (QS. 43:19). Dalam Etika Pemasaran Islam, hal demikian itu tidak etis dilakukan oleh seorang customer relation advisor maupun salesman untuk over-praise sebuah produk dan atribut terhadap kualitas yang sesungguhnya tidak dimiliki (Ibn al-Ukhuwwah, 1983). Etika pemasaran Islam memiliki aturan berikut: (a) Hindari iklan palsu dan menyesatkan; (b) Menolak tekanan manipulasi, atau taktik penjualan yang menyesatkan; (c) Hindari promosi penjualan yang menggunakan penipuan atau manipulasi.

Teknik promosi juga tidak boleh menggunakan daya tarik seksual, daya tarik emosional, daya tarik rasa takut, kesaksian palsu dan daya tarik penelitian semu, atau berkontribusi terhadap kebodohan pikiran atau mendorong pemborosan. Metode ini tidak etis karena mereka digunakan murni untuk mengeksploitasi naluri dasar konsumen hanya untuk memperoleh keuntungan dan pangsa pasar yang lebih besar. Selain itu, etika Islam secara tegas melarang stereotype perempuan dalam iklan, dan penggunaan "fantasi" yang berlebihan. Penggunaan bahasa suggestive, perilaku, dan penggunaan perempuan sebagai obyek untuk memikat dan menarik pelanggan juga tidak diperbolehkan.

\section{Place: ChannelsDistribution.}

Fokus pada distribusi produknya. Dimensi etis pengambilan keputusan yang berkaitan dengan distribusi sangat penting di bidang pemasaran. Dalam hal ini, prinsip-prinsip Islam sangat menjunjung tinggi kebijaksanaan dan keadilan bagi kedua pihak, yakni: (1) Tidak memanipulasi ketersediaan produk; (2) Tidak menggunakan paksaan; (3) Tidak mempengaruhi yang tidak semestinya; (4) Desain kemasan produk harus pantas dengan proteksi yang memadai; (5) Produk berbahaya dan beracun harus diberikan keamanan tinggi; (6) Tidak mengangkut produk melebihi kapasitas kendaraan; (7) Jenis kendaraan angkutan tertentu harus diatur waktunya pada jam tertentu. (8) Jatah preman, oknum petugas, dsb sangat menghambat saluran distribusi.Tujuan utama saluran distribusi prinsip Islam harus menciptakan nilai dan mengangkat 
standar hidup dengan menyediakan layanan etis dan memuaskan.

People. Islam menekankan pentingnya "bebas" dan "penilaian independen" sebagai bagian dari pelanggan. Mampu berpikir rasional ketika membuat keputusan terkait kegiatan pemasaran global merupakan prasyarat dalam hukum Islam. Masyarakat harus bebas dari paksaan / 'ikrah' informasi pemasaran(QS. 23:7).Menurut prinsip Islam, daya tarik seksual, emosional, rasa takut, iklan subliminal dan pseudo klaim ilmiah semua memiliki unsurunsur pemaksaan yang dikategorikan sebagai hal yang tidak etis sebagai sarana pemasaran. Karenanya Etika marketing-mixmenyatakan bahwa kebebasan pengambilan keputusan pelanggan harus dilindungi dari semua unsur pemaksaan dalam bentuk apapun. Berikut adalah "Model Komunikasi Pemasaran Islami" dan "Konstelasi Aplikatif Teori terhadap Objek Kajian" dalam penelitian ini, sebagai berikut:

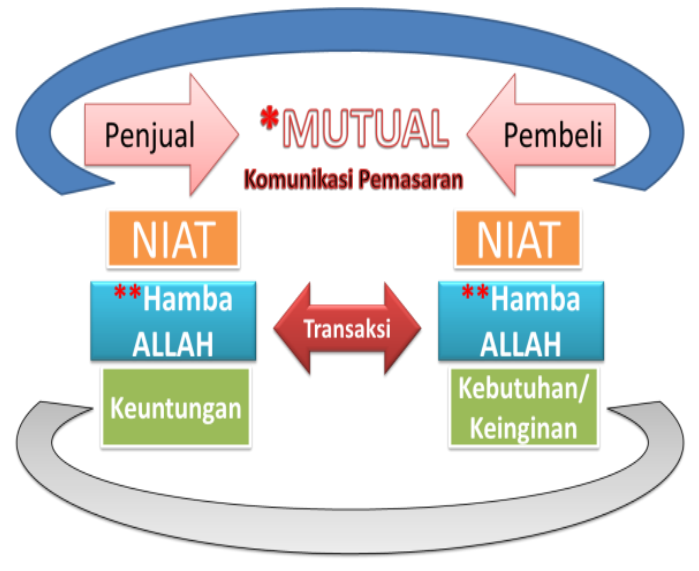

Gambar 3.

Model Komunikasi Pemasaran Islami (Reformulasi dari "Islamic Principles of Marketing by Suhail Nadeem")

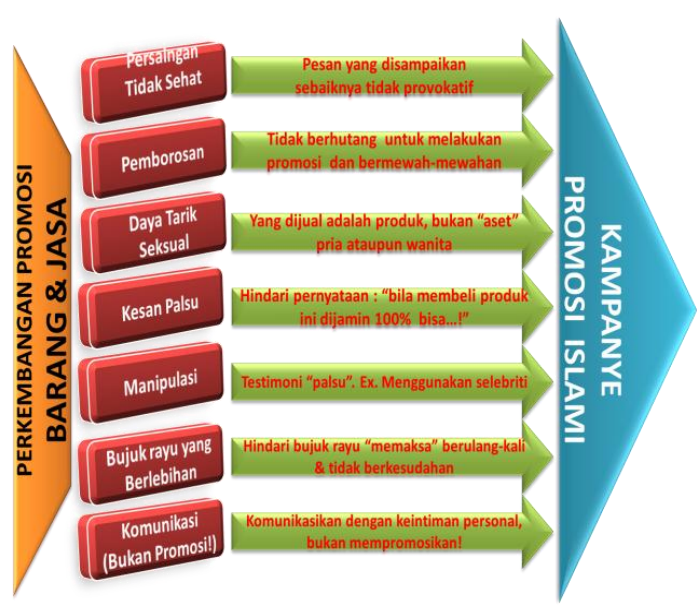

Gambar 4.

(Reformulasi dari Suhail Nadeem, 2011)

Konstelasi Aplikatif Teori \& Objek Penelitian

\section{METODE PENELITIAN}

Penelitian ini menggunakan metode deskriptif kualitatif. Jalaluddin Rakhmat mengutarakan bahwa penelitian deskriptif kualitatif adalah penelitian yang hanya memaparkan situasi ataupun peristiwa, penelitian ini tidak mencari atau menjelaskan hubungan, tidak menguji hipotesis ataupun membuat prediksi. Selain itu penelitian deskriptif kualitatif bertujuan untuk: (1) Mengumpulkan informasi aktual secara rinci yang melukiskan gejala yang ada; (2) Mengidentifikasi masalah atau memeriksa kondisi praktek-praktek yang berlaku; (3) Membuat perbandingan atau evaluasi; (4) Menentukan apa yang dilakukan 
orang lain dalam menghadapi masalah yang sama dan belajar dari pengalaman mereka untuk menetapkan rencana dan keputusan dimasa mendatang. (Rakhmat, 2002:44)

Berdasarkan beberapa definisi tersebut disimpulkan bahwa penelitian ini melakukan beberapa langkah metodologis guna menjawab tujuan dari penelitian ini: (1) Wawancara dan observasi. (2) Memaparkan dan membandingkan teori-teori pemasaran konvensional dan pemasaran syariah. (3) Melakukan reformulasi model pemasaran syariah. (4) Menggunakan model tersebut untuk mengkategorisasi,menganalisa, dan menyimpulkan hasil penelitian secara terencana dan sistematis.

\section{HASIL PENELITIAN DAN PEMBAHASAN}

\section{Pertama, Persaingan Tidak}

Sehat. Maksudnya adalah, pesan yang disampaikan untuk melakukan promosi terkesan dan dirasa provokatif.Persaingan tidak sehat dalam tubuh PT. H2O ini dibagi kedalam dua hal: (1) persaingan tidak sehat dari Internalberupa persaingan antar sesama staf karyawan dalam hal pembagian tugas, peran dan tanggung jawab pekerjaan. (2) persaingan tidak sehat dari Eksternal perusahaan,berupa antar perusahaan sejenis dalam melakukan penetrasi pasar dan aktifitas promosi kepada target pasar. Kedua

Pemborosan. Maksudnya, bahwa segala aktifitas perusahaan dan promosinya tidak berhutang dan bermewah-mewahan. Seluruh direksi manajemen PT. H2O tidak ada yang memperkaya diri sendiri. Terbukti dari gaya hidup dan penampilan mereka sehari-harimencerminkan

kesederhanaan tidak bermewahan. Ketiga, Daya Tarik Seksual. Maksudnya adalah, produk-produk barang maupun jasa yang ditawarkan, dipromosikan yang dijual oleh $\mathrm{H} 2 \mathrm{O}$ adalah memang produk barang maupun jasa tersebut. Artinya, penawaran melalui promosi tidak ditekankan dengan menggunakan daya tarik seksual pria maupun wanita.

\section{Keempat,Kesan}

Palsu.

Maksudnya adalah informasi yang disampaikan mengenai produk barang dan jasa yang ditawarkan PT. H2O tidak berkesesuaian dengan kondisi, khasiat dan manfaat yang didapat. Seluruh calon jamaah diberikan informasi akurat dan apa adanya dari para perwakilan maupun marketing PT. H2O. tidak ada yang dikesankan palsu. Namun memang terkadang ada saja para calon jamaah yang merasa tidak nyaman dengan konsep dan produk yang ditawarkan.Hal ini disebabkan oleh beberapa faktor seperti: minimnya informasi yang didapat, perbedaan keyakinan dan pemahaman tentang hukum dan tata cara Islam, serta perbedaan nilai dan budaya setempat. Kelima, Manipulasi. Cukup banyak ragam atau bahasanya sekarang, dikenal dengan istilah "modus" yang dikategorikan kedalam manipulasi. 
Misalnya testimoni palsu dengan menggunakan selebriti atau para tokoh maupun pemimpin. Dengan transaksi tertentu mereka diminta untuk memberikan keterangan ataupun testimoni "palsu" yang sesungguhnya tidak mereka rasakan.Keenam, Bujuk Rayu Yang berlebihan.Bujuk rayu yang berlebihan dapat membuat calon konsumen atau pelanggan merasa tidak nyaman mendengarkan bentuk personal selling yang dikomunikasikan oleh pemasar. Bahkan tidak jarang terkesan memaksakan kehendak si pemasar.

Terakhir, Komunikasi (Bukan Promosi!). Maksudnya adalah sudah sepantasnya seorang penjual atau marketing mengkomunikasikan produk barang maupun jasa yang dijualnya kepada calon pembeli/pelanggan secara jujur dan bersahabat membangun keintiman berkomunikasi.

Peneliti merumuskan konstelasi aplikatif teori dan objek penelitian untuk kemudian dijadikan beberapa tema besar pertanyaan yang diajukan kepada para personil PT. H2O. kemudian ditentukan nilai-nilai Islami dalam aktifitas promosi yang dilakukan oleh PT. H2O yang terkategorisasi ke dalam beberapa dimensi. Berikut pembahasan dimensinya satu demi satu:

\section{Pertama, Persaingan Tidak}

Sehat. Merujuk pada QS. 2:282.Merupakan perkara yang merusak apabila antara penulis dan saksi saling menyulitkan dalam transaksi bisnis. Yang dimaksud'penulis' adalah penjual dan pembeli yang melakukan kegiatan transaksi. Begitu pula dengan QS. 4:29. Ayat ini jelas melarang persaingan yang tidak sehat di dalam kegiatan bisnis.

Dalam pandangan umum, persaingan bisnis sering diartikan sebagai usaha 'perlawanan' dengan skenario Win-Lose untuk mematikan atau menjatuhkan pengusaha lainnya dan memandang pebisnis lainnya sebagai musuh baginya. Paradigma seperti ini sering mengakibatkan pebisnis jatuh ke dalam persaingan bebas atau persaingan tidak sehat dengan tidak memperhatikan lagi baik buruk dan halal haram serta dampaknya bagi lingkungan dan masyarakat sekitar, terlebih lagi generasi penerus berikutnya. Karena pepatah mengatakan "apa yang ditanam hari ini akan dituai hari esok" oleh generasi setelah kita. Sementara dalam paradigma dan prinsip Islam menganggap persaingan sebagai perlombaan dengan skenario Win-Win dan menganggap pengusaha lainnya sebagai rekan bisnis yang dapat saling menguntungkan dan berlomba-lomba dalam kebaikan, seperti yang dijelaskan pada QS. 2:148. Bergegas dalam melakukan kebaikan kepada diri sendiri terlebih dengan orang lain (hablun minan naas) baik muslim maupun nonmuslim dalam hal apapun.

PT. H2O dalam cuplikan wawancara, banyak yang mencibir, mencemooh, mengkritisi tajam bahkan menghina usaha bisnisnya. Faktor utamanya adalah karena sampai saat ini dengan beberapa bidang usaha yang dimilikinya, $\mathrm{H} 2 \mathrm{O}$ mampu berbagi 
secara syariah dengan cara menopang dan menyicil sebesar 2 hingga $2.5 \%$ per bulan yang ditambahkan ke dana setoran awal para calon jamaah umroh maupun haji, dengan biaya yang tentunya relatif minim tergantung dengan pilihan bulan dan tahun pemberangkatannya.

Kedua, Pemborosan. Konsep AlQur'an melarang pemborosan dalam hal apapun, QS. 17:26-27. Konsumsi berlebih-lebihan, yang merupakan ciri khas masyarakat yang tidak mengenal Rab-nya, dikutuk dalam Islam dan disebut dengan istilah israf (pemborosan) atau tabzir (menghamburkan uang dan harta tanpa guna). Beberapa contoh pemborosan adalah : (1) Membeli produk mahal atas dasar gengsi; (2) Suka belanja dengan kartu kredit tanpa melihat daya beli; (3) Boros penggunaan energi (bahan bakar); (4) Besar pasak daripada tiang (kecuali penghasilan rendah); (5) Suka menyisakan dan membuang makanan; (6) Membeli barang hanya karena suka padahal tidak dibutuhkan; (7) Boros pemakaian pulsa telepon, bensin, gas, air dan lain-lain; (8)Membela hobi berbiayamahal tanpa menghiraukan keadaan lingkungan sekitar.

Pemborosan adalah konsumsi yang berlebihan, terlebih dalam berbisnis. Terdapat perbedaan mendasar antara perilaku konsumen Muslim dengan perilaku konsumen Konvensional. Konsumen Muslim dalam memenuhi kebutuhan kesehariannya berpedoman pada dua hal; yang pertama adalah "hablun minannas" hubungan antar sesama manusia yang dalam hal ini sengaja peneliti batasi dengan "Kuu anfusakum wa ahlikum naaro", dalam arti jagalah dengan menafkahi dirimu dan keluargamu terlebih dahulu. Kemudian yang kedua adalah "hablun minaulloh" hubungan antara manusia dengan Allah, dalam arti seorang konsumen Muslim yang taat sudah tentu berpikir untuk mencari ridha Allah dengan cara membelanjakan sebagian pendapatannya di jalan Allah "fii sabilillah”. Dalam Islam perilaku seorang konsumen Muslim harus mencerminkan hubungan kedua hal tersebut, yakni hubungan sesama manusia dan hubungan manusia dengan Allah Yang Maha Esa.

Konsep inilah yang tidak kita temui dalam ilmu perilaku konsumen konvensional. Juga tidak kita temui pada kajian perilaku konsumsi dalam perspektif ilmu ekonomi konvensional adalah, bahwa dalam perspektif ilmu ekonomi syariah terdapat pola dan aspek keseimbangan antara belanja kebutuhan konsumsi individu dan belanja kebutuhan 'konsumsi sosial' seorang Muslim. Al-Qur'an mengajarkan ummat Islam agar menyalurkan sebagian pendapatan dan rezekinya dalam bentuk zakat, infaq, shodaqoh. Ketiga bentuk 'konsumsi sosial' ini sesungguhnya praktis menegaskan dengan gamblang bahwa sesama ummat Islam merupakan mata rantai yang kokoh dan saling 
menguatkan bagi ummat Islam lainnya. Namun pertanyaan selanjutnya muncul, mengapa ummat Islam dunia dan khususnya di Indonesia seperti (secara praktis) dalam banyak hal "terkurung dalam sangkar emas" oleh kaum minoritas?Pertanyaan ini sangat menarik perhatian periset untuk menjawabnya pada kesempatan kajian penelitian selanjutnya.

Selama H2O mampu memenuhi segala janji-janji promosi dan pemasarannya, $\mathrm{H} 2 \mathrm{O}$ belum dapat dikategorikan sebagai melakukan pemborosan. Dan tentunya $\mathrm{H} 2 \mathrm{O}$ telah memperhitungkan pengelolaan keuangannya dengan matang antara kebutuhan individu (hablun minaulloh) maupun kebutuhan sosial (hablun minannaas), seorang konsumen Muslim pada prinsipnya berpedoman pada mendapatkan ridho Allah.

Ketiga, Daya Tarik Seksual. (A) Sudut Pandang Konvensional. Persaingan bisnis yang kompetitif akan semakin memicu para eksekutif perusahaan untuk selalu berpikir kreatif dan inovatif untuk mengkomunikasikan pesan-pesan yang dipasarkannya dengan menonjolkan keunikan, dan tampil beda, bahkan atas nama 'kreatifitas' daya tarik seksual pun 'diekspose' habis-habisan. Hal ini dilakukan agar perusahaan dapat unggul dan kempetitif untuk keberlangsungan hidup perusahaan. Caranya tentu dengan melakukan kegiatan promosi dimana dalam baurannya terdapat unsur iklan cetak maupun elektronik yang berperan penting dan masih cukup efektif dalam menyampaikan pesanpesannya. Selain penentuan dan penggunaan media yang tepat, dalam menyampaikan pesan-pesan di media, iklan harus cukup kreatif dan juga diharapkan harus mampu memelihara dan meningkatkan competitive advantage merek produk barang maupun jasa yang diiklankan. Faktor penting lainnya adalah faktor stimulus dan respon. Ini berarti ketika iklan dibuat, maka ada respon dari konsumen.

Secara terminologi, seks berarti jenis kelamin, sedangkan seksual berarti hal yang berkaitan dengan masalah hubungan intimasi (mis: komunikasi verbal/non verbal, persetubuhan) antara laki-laki dan perempuan. Daya tarik seks digunakan untuk menarik perhatian yang menimbulkan efek khusus yang membangkitkan berbagai tingkat emosi/sugesti seksual, dan untuk membujuk khalayak dengan cara menggugah hasrat seksualnya. Khalayak pada tahap awal interaksi komunikasi khususnya iklan, diberi stimulus berupa rangsangan seksual. Kemudian pada saat mereka sudah terexspose/terstimulus, maka janji komersil pun disisipkan. Daya tarik seks ini, minimal menggunakan gambar yang berperan penting untuk menghasilkan stimulus seksual.

Dirujuk dari berbagai kajian literatur dan penelitian ilmiah, daya tarik seks mempunyai kemampuan tinggi untuk menarik minat beli khalayak luas. Seks merupakan elemen 
yang mampu memancing minat secara serentak baik pada pria maupun wanita. Ada 2 kategori iklan dengan daya tarik seks, yakni sugesti seks dan nudity. "Sugesti seks" merupakan penggambaran situasi yang bertema romantika seperti model wanita cantik atau pria tampan yang ditampilkan 'berpose gaya tertentu' ataupun sedang bermesraan/berciuman. "Nudity" yakni penggambaran model iklan pria ataupun wanita yang memakai pakaian sangat minim/bahkan dalam keadaan tidak berpakaian namun ada teks/konteks/konten ataupun background yang menutupi bagian terbuka tersebut. Adapun bentuk daya tarik dasar yang sering digunakan dalam dunia periklanan terdiri atas:(1)Daya tarik rasio (rational appeal), yang berfungsi untuk mengkomunikasikan secara langsung informasi mengenai produk/layanan; (2) Daya tarik emosi (emotional appeal), yang berusaha mempengaruhi perasaan/emosi khalayak. Termasuk dalam jenis ini antara lain imbauan menakut-nakuti, daya tarik humor, daya tarik kekuasaan, dan daya tarik seks.

(B) Sudut Pandang Islam.

Nabi Muhammad (SAW) melarang segala bentuk transaksi yang berada di bawah paksaan. Menurut prinsip-prinsip Islam, daya tarik seksual, daya tarik emosional, daya tarik ketakutan, iklan subliminal dan pseudo klaim ilmiah semua memiliki unsur-unsur pemaksaan yang menyebabkan mereka dikategorikan sebagai hal yang tidak etis sebagai sarana pemasaran maupun saran aktifitas komunikasi pemasaran. Etika marketing mix maupun marketing communication mix, karenanya, menyatakan bahwa kebebasan pengambilan keputusan pelanggan harus dilindungi dari semua unsur pemaksaan dalam bentuk apapun.

Umumnya daya tarik seks sering merugikan kaum hawa. Industri media massa secara langsung maupun tidak telah 'menjebak' wanita ke dalam lingkaran syetan baik pelakunya maupun pemirsanya. Aspirasi mereka dikontrol dan dibatasi oleh gagasan yang mereka peroleh dari media itu sendiri, dan terkadang media bersifat paradoks. Satu sisi media menonjolkan prestasi-prestasi dan berbagai kemajuan pencapaian wanita, disisi lain media juga 'menjerumuskan' wanita kepada 'keterbelakangan' dengan tetap menonjolkan keutamaan wanita seperti 'bagian fisik tubuh' dan 'suara' sebagai makhluk Allah yang secara kodrat mampu menarik perhatian kaum Adam.

Sedemikian halus, sekilas logis dan terkesan sebagai hak asasi manusia pesan-pesan media tersebut. Hingga para pemirsa wanita itu sendiri tidak sadar bahwa sesungguhnya mereka digiring kepada suatu ideologi tertentu dimana sesungguhnya bertentangan dengan nilai-nilai Islam tentang identitas, peran dan kodrat mereka. Islam mengajarkan dalam banyak ayat Al-Qur'an seperti dalam QS. 7:26. dan QS. 49:13. Kedua ayat tersebut menegaskan kepada ummat manusia 
baik pria maupun wanita untuk berpakaian menutup aurat dan Takwa adalah sebaik-baik pakaian. Dan maksud dari menutupi perhiasan bukanlah perhiasannya yang ditutup, melainkan bagian tubuh yang dipasangkan perhiasan. Pemahaman tersirat lainnya adalah bahwa dalam hal ini wanita adalah makhluk Allah sama dengan pria, yang kualitasnya di hadapan Allah diukur dari ketaqwaannya, bukan terletak pada fisiknya ataupun kemampuannya memuaskan pria. Pada ayat selanjutnya di QS. 24:31, dijelaskan terperinci tentang batasan aurat dan siapasaja yang boleh melihat aurat wanita maupun pria.

Daya pikat lainnya dari wanita adalah suaranya. Firman Allah dalam QS. 33:32.Suara wanita jika dikeluarkan dengan biasa dan wajar, akan terdengar biasa-biasa saja. Namun jika suara itu sengaja dilemahlembutkan, akan menimbulkan daya pikat tersendiri. Itulah sebabnya AlQur'an melarang istri-istri Nabi Muhammad SAW melemah lembutkan suara mereka, khawatir didengarkan oleh orang yang mempunyai hati yang 'sakit' (kotor hatinya). Di zaman modern sekarang ini hal-hal demikian itu, pekerjaan pikat-memikat dari seorang wanita kepada pria atau sebaliknya, sudah jauh melebihi dari apa yang diterangkan dalam Al-Qur'an. Bahkan sudah menjadi trend dan mode dengan ilmu spesialis tersendiri bahkan ada ahli dan perancangnya. Dari soal mode pakaian, dandanan seksi, perhiasan dan aksesoris yang menambah kesan feminin seorang wanita, parfum yang mendebarkan hati, tarian erotis dan menggairahkan birahi, dan sebagainya.Bukti Islam memuliakan wanita adalah Al-Qur'an sendiri memberikan perhatian khusus yang demikian tinggi pada persoalanpersoalan perempuan dengan mencantumkan surat ke empat 'AnNisaa' yang berarti 'Perempuan'.

$\mathrm{H} 2 \mathrm{O}$ adalah brand asli Indonesia yang baru muncul dengan produk jasa Haji dan Umroh. H2O tidak melakukan iklan apapun dalam bentuk daya tarik seksual apapun. Brosur dan website-nya pun tidak menampilkan wajah wanita berparas cantik nan rupawan sekalipun modelnya berjilbab dan menutup aurat. Kesimpulannya adalah para nara sumber tidak pernah berpikir untuk beriklan dengan menonjolkan daya tarik seksual, khususnya barangkali yang mendekati seperti wanita berjilbab dengan paras cantik di brosur maupun pamflet $\mathrm{H} 2 \mathrm{O}$, dan itu tidak ada dan tidak berlaku bagi $\mathrm{H} 2 \mathrm{O}$, paling tidak untuk saat penelitian ini berlangsung.

Keempat, Kesan Palsu.Kesan palsu termasuk ke dalam "Hukum Haram Selain Zatnya" kategori Tadlis (penipuan). Dalam aktifitas promosi, testimoni atau kesaksian dalam bentuk iklan yang tidak benar-benar dialami dan dirasakan oleh seorang saksi dapat dikategorikan sebagai kesan palsu. Promosi berbentuk iklan ini memiliki etikanya sendiri, prinsip etika iklan 
dalam aktifitas bisnis dan komunikasi pemasaran adalah prinsip kejujuran, yakni mengatakan yang benar dan tidak menipu. Prinsip ini bersifat 'reciprocal', artinya tidak hanya menyangkut kepentingan banyak orang, namun juga menyangkut kepentingan perusahaan produsen iklannya serta bisnis keseluruhannya sebagai sebuah profesi yang baik yang senantiasa harus menjaga citra baik pula. Berdasarkan prinsip kejujuran ini, promosi atau iklan yang baik dan diterima secara etika moral adalah promosi atau iklan yang memberi pernyataan atau informasi yang benar sebagaimana adanya kondisi produk barang atau jasa yang ditawarkan.Al-Qur'an sendiri telah mengajarkan kita akan kejujuran di dalam QS. 9:119. Sudah sepantasnya seorang Muslim menjunjung tinggi prinsip kejujuran. Keharusan bersikap jujur dalam berniaga sudah diterangkan secara tegas dan gamblang dalam QS. $6: 152$.

$\mathrm{H} 2 \mathrm{O}$ dalam melakukan usahanya telah menegakkan prinsip kejujuran. Memang banyak orang yang mencibir dengan pola investasi yang dijalankan oleh $\mathrm{H} 2 \mathrm{O}$ ini, terkesan berlebihan dan menipu karena pembagiannya terlalu besar diatas ratarata bunga bank. Namun $\mathrm{H} 2 \mathrm{O}$ menjawabnya dengan cara membuktikannya langsung dengan konsep yang gamblang tertera di brosur yakni Tabungan Tabarru' yaitu pemberian sukarela dari $\mathrm{H} 2 \mathrm{O}$ kepada para jamaahnya sebesar $2 \%$ hingga $3 \%$ setiap bulan untuk ditambahkan sebagai tabungan haji dan umroh mereka hingga batas waktu yang disepakati bersama.

Kelima, Manipulasi.Manipulasi termasuk ke dalam "Hukum Haram Selain Zatnya" juga kategori Tadlis (penipuan), seperti kesan palsu. Kesan palsu maupun manipulasi tersoroti memiliki prinsip yang sama yakni Kejujuran. Namun yang membedakannya adalah, kesan palsu khusus dititikberatkan pada produk barang maupun jasanya. Sedangkan manipulasi cenderung kepada cara si penyampai pesan (pemasar) melakukan aktifitas komunikasi dan menyampaikan maksud serta tujuannya mengenai barang atau jasa yang ditawarkannya itu.

Seperti halnya 'mengkondisikan' seorang selebriti, tokoh/pemuka agama ataupun jamaah haji dan umroh yang pernah berangkat bersama $\mathrm{H} 2 \mathrm{O}$ untuk memberikan kesaksian ataupun testimoni palsu yang sesungguhnya belum atau bahkan tidak pernah mereka rasakan atau dapatkan, atau melebih-lebihkan konten-nya sebagai kesaksian palsunya dengan tujuan mendongkrak penjualan atau menaikkan citra perusahaan. Sepanjang pengamatan peneliti, H2O belum pernah melakukan hal-hal tersebut. H2O mengedepankan keterbukaan dan komunikasi apa adanya. Bahkan informanI dan informanII menyatakan bahwa hal-hal demikian seperti menggunakan seorang publik figur atau tokoh agama belum perlu di $\mathrm{H} 2 \mathrm{O}$, 
karena $\mathrm{H} 2 \mathrm{O}$ merasa sudah sangat jelas menentukan keberadaan dan positioning perusahaannya. Inilah yang dimaksud dengan keterbukaan, kekeluargaan dan komunikasi di lingkungan $\mathrm{H} 2 \mathrm{O}$.

\section{Keenam, Bujuk Rayu}

Berlebihan.Bujuk rayu berlebihan juga termasuk kategori bentuk transaksi yang berada di bawah paksaan atau "bay 'alMudtarr". Bujuk rayu berlebihan ini sama dengan memaksakan kehendak, seorang pemasar memaksakan kehendaknya kepada calon pembeli untuk dibeli produk dagangannya dengan "berbagai cara yang tak berkesudahan". Misalnya yang saat ini sedang nge-trend di pinggiran jalan seorang sales promotion girl(SPG), seorang perempuan cantik biasanya remaja menjajakan rokok dengan melakukan strategi pemasaran direct selling, personal selling dan Word of mouth sekaligus. Untuk menjadi seorang SPG rokok setidaknya harus memenuhi tiga standar kriteria utama yakni:

1. Performance. Halini merupakan $100 \%$ tampilan fisik yang dapat dilihat dengan mata telanjang. Dalam perspektif ini, performance juga mengilustrasikan tentang celana atau bawahan yang dipakai oleh SPG. Bawahan ini diukur dari penampilan fisik dan desain pakaian, ukuran bawahan ini subyektif (setiap orang dimungkinkan berbeda).

2. Communicating Style. Mutlak harus terpenuhi oleh seorang SPG, karena melalui komunikasi ini akan mampu tercipta interaksi antar konsumen dengan SPG. Komunikasi ini diukur dari gaya bicara dan cara berkomunikasi.

3. Body Language.Lebih mengarah pada gerak fisik (lemah lembut, lemah gemulai, dan lainnya), gerak tubuh ketika menawarkan produk dan sentuhan fisik 'body touch'.(http://digilib.uinsby.ac.id/8647/ 6/bab.iii.pdf)

Ilustrasi dari hasil penelitian tersebut jelas merupakan fakta yang saat ini sedang fenomenal di dunia promosi industri rokok perusahaan kapitalis. Bujuk rayu berlebihan sudah tentu terjadi dalam transaksi antara SPG dan konsumennya yang mayoritas laki-laki. Memang pada akhirnya transaksi terjadi karena suka sama suka. Namun cara dan proses transaksi itu berlangsung tertanam nilai-nilai kebathilan yang dilarang oleh Islam seperti ditegaskan dalam QS. 4:29. Istilah "Suka sama suka" dalam terjemahan ayat tersebut disini tentunya dengan cara, proses dan jalan yang benar menurut syariat Islam dan bukan sebaliknya.

$\mathrm{H} 2 \mathrm{O}$ dalam melakukan promosinya tentu saja tidak se-ekstrim SPG rokok yang melakukan bujuk rayu berlebihan seperti dijelaskan diatas. Mendekati konsumen dengan terusmenerus dan berulang-ulang kali berbicara yang tidak berkesudahan, serta terlalu memaksa pun juga termasuk bujuk rayu yang berlebihan. Indikatornya adalah ketika konsumen merasa sudah tidak nyaman 
mendengarkan ocehan seorang pemasar, disitulah maksud dari bujuk rayu berlebihan berlaku. Sementara H2O tidak pernah melakukan hal-hal sedemikian itu, dalam beberapa kesempatan $\mathrm{H} 2 \mathrm{O}$ cukup memperkenalkan diri mereka sebagai perusahaan yang bergerak di bidang travel haji dan umroh, kemudian sedikit menjelaskan pola akad dan kerjasamanya serta produk-produknya berikut beberapa usaha yang dimilikinya. Tidak ada paksaan dalam hal ini.

Ketujuh, Komunikasi (Bukan Promosi!). Yang pertama, komunikasi dimaksud berkaitan erat dengan QS. An-Nisa ayat 63. Penggalan ayat ini adalah "Qoulan Baligha" dimaknai sebagai menggunakan kata-kata yang efektif, efisien, tepat sasaran, mudah dimengerti dan komunikatif. "Perkataan yang berbekas pada jiwa mereka" bermakna mendalam bila dikaitkan dengan komunikasi yang efektif pada kegiatan promosi. Sepatah perkataan tidak akan 'membekas' bila ada motif menjebak ataupun kebohongan terselubung, ingin cari untung sendiri dan merugikan lawan bicaranya. Namun sebaliknya, perkataan yang baik akan 'membekas' di hati bila kita mengkomunikasikannya dengan membangun keintiman, berniat baik dan ingin membantu serta berbagi, tidak ada motif jelek apalagi mau menang sendiri.

Komunikasi yang efektif mampu memahami konsumen sebagai lawan bicara menggunakan bahasa yang sesuai dengan situasi, kondisi dan tingkat intelektualitas konsumen dengan bahasa sederhana yang mudah dimengerti oleh konsumen. Demikian juga dalam melakukan promosi hendaknya menggunakan bahasa yang mudah dipahami oleh target pasar dan pelanggan sehingga pesan yang ingin disampaikan oleh perusahaan (sales/ marketing) dapat diterima dengan baik oleh masyarakat.

$\mathrm{H} 2 \mathrm{O}$ dengan konsep program "Tabungan Tabarruk dan Jalinan Silaturahim Syariah". Konsep ini berusaha menyentuh komunitas secara kekeluargaan dan kebersamaan. Komunikasi yang dibangun adalah keintiman dan silaturahim, bukan semata-mata promosi. Tidak ada motif paksaan dan tekanan untuk mengikuti program-program H2O. Namun karena Jalinan Silaturahim yang dibangun 'sarat' dengan makna dan nilai-nilai kekeluargaan sehingga membuat para calon jamaah merasa nyaman dan mempercayakan proses keberangkatan ibadah haji dan umrohnya di $\mathrm{H} 2 \mathrm{O}$.

\section{KESIMPULAN}

Dalam etika Islam, teknik promosi tidak dibenarkan menggunakan daya tarik seksual, daya tarik emosional, daya tarik rasa takut, kesaksian palsu dan daya tarik penelitian semu, atau berkontribusi terhadap kebodohan pikiran atau mendorong pemborosan. Dalam kerangka Islam, metode ini tidak etis karena mereka digunakan murni untuk 
mengeksploitasi naluri dasar konsumen di seluruh dunia dengan tujuan untuk memperoleh keuntungan dan pangsa pasar yang lebih besar. Selain itu, etika Islam secara tegas melarang stereotip (stereotype) perempuan dalam iklan, dan penggunaan "fantasi" yang berlebihan. Penggunaan bahasa sugestif (suggestive) dan perilaku, serta penggunaan perempuan sebagai obyek untuk memikat dan menarik pelanggan juga tidak diperbolehkan.Setidaknya ada tujuh kesimpulan dari hasil wawancara dan observasi serta pembahasan tentang subjek dan objek penelitian ini adalah sebagai berikut:

\section{Pertama, Persaingan Tidak}

Sehat. Yang dimaksud adalah persaingan tidak sehat antar sesama karyawan H2O, antar sesama perwakilan di daerah, dan perusahaanperusahaan lain yang menjelek-jelekkan H2O. Kedua, Pemborosan.Prinsipnya, kegiatan yang dilakukan $\mathrm{H} 2 \mathrm{O}$ tidak melakukan pemborosan. Ketiga, Daya Tarik Seksual.H2O tidak pernah memunculkan pesan yang berpotensi pada daya tarik seksualitas padaseluruh pesan verbal maupun non verbal yang disampaikan melalui berbagai media seperti brosur dan spanduk,. Keempat, Kesan Palsu.Hasil observasi membuktikan bahwa sejauh ini kinerja perusahaan dalam hal janji-janji dan pemberangkatan jamaah tidak terkendala dan tidak ada kesan palsu. Kelima, Manipulasi.H2O tidak pernah 'bersekongkol' ataupun menggunakan selebritis maupun tokoh terkenal dalam aktifitas komunikasi pemasarannya untuk memberikan testimoni palsu.

Keenam, Bujuk Rayu Yang Berlebihan.Seluruh aktifitas pemasaran dan promosi tidak ada yang berlebihan dan menyimpang dari informasi yang diberikan dari kantor pusat H2O. Para perwakilan dan pemasar mengerti aturan yang berlaku dan memahami produk yang mereka pasarkan serta sebatas apa mereka dapat berimprovisasi dalam memasarkannya. Ketujuh, Komunikasi (Bukan Promosi!).Para staf dan tim pemasaran $\mathrm{H} 2 \mathrm{O}$ melakukan promosiapa adanya serta tanpa ada paksaan apapun kepada siapapun. Membangun keintiman berkomunikasi kepada siapapun (dan bukan sekedar promosi) adalah prinsip dasar H2O. Keputusan sepenuhnya ditangan calon jamaah.

Begitulah Islam mengajarkan dan mengayomi (hukum dan tata cara "hablun minan naas") seluruh manusia sebagai manifestasi dari prinsip Islam dengan slogan "Rahmatan Lil 'Aalamiin" (QS. 21:107). Mereka yang menerima 'Rahmat' (tata cara dan hukum Islam) ini dan mensyukuri nikmat ini, baginya kebahagiaan di dunia dan akhirat. Dan mereka yang menolak dan membangkang dari 'Rahmat' ini, dia akan merugi di dunia dan akhirat seperti kaum-kaum terdahulu.

\section{DAFTAR PUSTAKA}

Al-Qur'anul Karim (Digital Qur'an ver 3.2) 
Al-Hadits. Tarjamah Shahih Bukhari. Diterjemahkan oleh Achmad Sunarto. 1992. Semarang: CV. Asy Syifa'

Al-Hadits. Tarjamah Shahih Muslim. Diterjemahkan oleh KH. Adib Bisri Musthofa. 1993. Semarang: CV. Asy Syifa'

Al-Arif, M.Nur Riyanto. 2010. DasarDasar Pemasaran Perbankan Syariah. Bandung: Alfabeta.

Ibn Al-Ukhuwwah, Diya' Al-Din Muhammad (1983) Ma'alim AlQurbah Fi Ahkam Al-Hisbah, Translated By Reuben Levy, Luzak, London.

Jefkins, Frank. 1997. Periklanan. Jakarta : Erlangga.

Kertajaya, Hermawan. 2005. Spiritual Marketing. Bandung: Mizan.

Kertajaya, Hermawan dan M. Syakir Sula. 2006. Syariah Marketing. Bandung: Mizan.

Kotler, Philip dan A.B. Susanto. 2000. Manajemen

Pemasaran Indonesia, Alih Bahasa oleh Ancella Anitawati dan Hermawan, Edisi Pertama, Jakarta : Salemba Empat.

Kotler, P. \& Armstrong, J. 2001. Dasardasar Pemasaran. (Alexander Sindoro, Penerjemah). Jakarta: PT. Index.

Kotler, Philip., Kertajaya, Hermawan., Huan Hooi Den., dan Liu Sandra, 2003. Rethinking Marketing: Sustainable Marketing Enterprise di Asia. Dialihbahasakan oleh Marcus P.
Widodo dari buku Rethingking Marketing: Sustainable Marketing Enterprise in Asia. Cetakan I. Pearson Education, Asia, Jakarta: PT. Prenhallindo.

Nadeem, Suhail 2011. "Islamic Principles of Marketing”. Paper Presentation. ICIB.

Miller, A. \& Dess, G. G. 1996. Strategic Management (2nd Ed.). New York: McGraw Hill.

Prisgunanto, Ilham. 2006. Komunikasi Pemasaran: Strategi dan Taktik. Bogor: Ghalia Indonesia.

Purba, Amir dkk. 2006. Pengantar Ilmu Komunikasi. Medan: Pustaka Bangsa Press.

Rakhmat, Jalaludin. 2002. Psikologi Komunikasi Edisi Revisi. PT.Remaja Rosdakarya. Bandung.

Staton, J. William. 2000. Pengantar Bisnis Modern. Erlangga.

Tjiptono, Fandy. 2002. Strategi Pemasaran. Yogyakarta: Andi Publishing.

\section{Jurnal:}

Damirachi, G., \& Shafai, J... (2011). "A Guideline to Islamic Marketing Mix". Interdisciplinary Journal of Contemporary Research in Business, 3(3), 1339-1347. Retrieved October 5, 2011, from ABI/INFORM Global. (Document ID: 2444075031).

Saeed, M., Ahmad, Z.U. And Mukhtar, S.M. (2001). "International Marketing Ethics From An 
Islamic Perspectives: A

Value Maximization Approach",

Journal Of Business Ethics,

32:127-142; Salesperson Selling

Behaviors On Customer

Satisfaction With Products."

Journal Of Retailing, 73(2): 171-

183.

\section{Sumber dari Internet:}

http://www.ncsu.edu/project/calscomm

blogs/economic/archives/2008/06/price

_versus_co.html 
